\title{
Hyperbaric oxygen therapy improves outcome of snake envenomation: tertiary center experience
}

\author{
Pradeoth Korambayil Mukundan1, Prashanth Varkey Ambookan', Ragu Angappan² \\ ${ }^{1}$ Department of Plastic Surgery, Jubilee Institute for Surgery of Hand, Aesthetic and Microsurgery, Thrissur 680005, Kerala, India. \\ ${ }^{2}$ Department of Plastic Surgery, Sushruta Cosmetic and Laser Surgery Centre, Coimbatore 641004, Tamil Nadu, India. \\ Address for correspondence: Dr. Pradeoth Korambayil Mukundan, Department of Plastic Surgery, Jubilee Institute for Surgery of Hand, \\ Aesthetic and Microsurgery, Bishop Alapatt Road, East Fort, Thrissur 680005, Kerala, India. E-mail: pradeoth@gmail.com
}

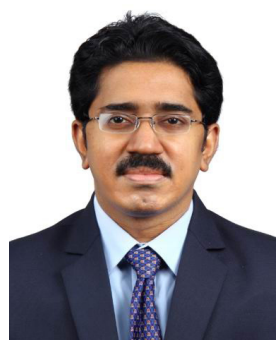

Dr. Pradeoth Korambayil Mukundan is a Consultant Plastic Surgeon in the Department of Plastic Surgery and Burns, Bahrain Defence Force Royal Medical Services, Kingdom of Bahrain - specializing in Hand surgery, Burns surgery and Microsurgery. He is interested in research on Hyperbaric medicine, its application in plastic surgery particularly in Burns and Trauma. More specifically, his work examines the utility of hyperbaric medicine and its function on molecular level of wound healing which helps in all spectrum of Plastic surgery.

\section{ABSTRACT}

Aim: Snakebite injuries of the extremities are common in tropical India among those involved in farming and outdoor activities. These injuries often complicated by cellulitis, gangrene, regional lymphadenopathy, compartment syndrome, bleeding abnormalities, septicemia, hypotension, and disseminated intravascular coagulation, resulting in significant morbidity and mortality. The purpose of the study is to share our experience of hyperbaric oxygen (HBO) therapy in the management of snakebite injuries. Methods: All patients who were treated for snakebite injuries in our department between October 2012 and October 2013 were included in the study. Results: Out of a total 395 patients, 174 patients treated with anti-snake venom with a mortality of 17 posttreatment. Forty-four out of the 174 patients was in the pediatric age group. Out of the patients referred to our department, 23 presented with cellulitis, 7 with compartment syndrome and 17 for the management of soft tissue cover over the extremities. Of the 47 patients, 30 involved the lower extremity and rest involved the upper extremity. All patients were subjected to $\mathrm{HBO}$ therapy as an adjunct. Six patients required flap cover: cross finger flap $(n=2)$, anterolateral thigh free tissue transfer $(n=1)$, lateral supramalleolar flap $(n=1)$, groin flap $(n=1)$, and dorsal metacarpal artery flap $(n=1)$. There was no need for fasciotomy among the patients who suffered impending compartment syndrome. Conclusion: HBO therapy may reduce the incidence of fasciotomy and increase the effectiveness of plastic surgical modalities if administered early and may be used as a useful adjunct in the management of snake envenomation injury.

Key words:

Hyperbaric oxygen therapy; snake bite injury; soft tissue reconstruction; upper and lower extremity

\begin{tabular}{|l|l|}
\hline \multicolumn{2}{|c|}{ Access this article online } \\
\hline Quick Response Code: & Website: \\
\hline & www.parjournal.net \\
\cline { 2 - 3 } & DOI: \\
\hline
\end{tabular}

This is an open access article distributed under the terms of the Creative Commons At tribution-NonCommercial-ShareAlike 3.0 License, which allows others to remix, tweak and build upon the work non-commercially, as long as the author is credited and the new creations are licensed under the identical terms.

For reprints contact: service@oaepublish.com

How to cite this article: Mukundan PK, Ambookan PV, Angappan R. Hyperbaric oxygen therapy improves outcome of snake envenomation: tertiary center experience. Plast Aesthet Res 2016;3:59-63.

Received: 03-02-2015; Accepted: 25-11-2015 


\section{INTRODUCTION}

Snakebite injuries of the extremities are common in India, among those involved in farming and outdoor activities. There are approximately 400 poisonous species among 2,000 species of snakes known worldwide. These species belong to the families of Elapidae, Viperidae,

Hydrophiidae, and Colubridae. ${ }^{[1]}$ Viper bites are the most common poisonous bites sustained by humans..$^{[2,3]}$ Russell's viper (Viperarusselli) is the most common species in South Asia and considered as an occupational hazard in the farming community. The World Health Organization has estimated that approximately 125,000 deaths occur from 250,000 poisonous snake bites worldwide every year. India alone accounts for 10,000 deaths. ${ }^{[4,5]}$ These snake bites involve predominantly young, healthy, and the able-bodied working population in rural areas. Children and the elderly are most susceptible to mortality. ${ }^{[5,6]}$ Most of these injuries involve the extremities. This results in pain and swelling of the bitten region, leading to cellulitis and compartment syndrome, in addition to systemic toxicity. The main cause of mortality is the lack of a systematic approach or protocol for the management of such injuries. The purpose of the study is to share our experience of multidisciplinary approach in the management of snakebite injuries of the extremities with various treatment modalities including hyperbaric oxygen (HBO) therapy, surgical debridement, and skin grafting, local or distant flaps to provide a treatment for effective management of such injuries from a plastic surgeon's perspective.

\section{METHODS}

All patients who were treated for snakebite injuries in our department between October 2012 and October 2013 were included in the study. All patients received tetanus toxoid. The snakebites were assessed by an emergency physician who classified them into poisonous and nonpoisonous snakebites clinically. Anti-snake venom (ASV) was administered accordingly. Antibiotics, diuretics, and blood products were administered as indicated. Patients were initially admitted to the Departments of Medicine or Pediatrics. They were only subsequently referred to the plastic surgery department if cellulitis, compartment syndrome or soft tissue loss was suspected. The treatment of soft tissue complications was done only after critical stabilization of the patient. Patients with cellulitis and compartment syndrome were subjected to HBO therapy. Administration of HBO therapy was done in a monoplace chamber where a single patient is placed in a chamber that is then pressurized to 1.8-2.4 atmospheres with $100 \%$ oxygen. HBO therapy was administered in 6 daily sessions, with each session lasting $90 \mathrm{~min}$. The sessions were extended according to the clinical progress of the disease judged by the clinician. The daily treatment sessions were extended another week if insufficient softness of the tissue was attained. The regimen for pediatric patients was identical, although parents were allowed to accompany the child in the chamber. Patients who presented with soft tissue necrosis were subjected to surgical debridement prior to 6 sessions of HBO therapy. The patients were followed up for the effects and complications of the treatment.

\section{RESULTS}

Of a total 395 patients, 174 patients treated with ASV with a mortality of 17 posttreatment. Forty-four out of the 174 patients were in the pediatric age group [Table 1]. Of the patients referred to our department, 23 presented with cellulitis, 7 with compartment syndrome, and 17 for the management of soft tissue cover over the extremities. Of the 47 patients, 30 involved the lower extremity and rest involved the upper extremity. All patients were subjected to HBO therapy as an adjunct. Six patients required flap cover: cross finger flap $(n=2)$, anterolateral thigh free tissue transfer $(n=1)$, lateral supramalleolar flap $(n=1)$, groin flap $(n=1)$, and dorsal metacarpal artery flap $(n=1)$ [Tables 2 and 3]. There was no need for fasciotomy among patients who suffered impending compartment syndrome.

\section{Case I}

A 5-year-old boy was admitted with a snakebite injury to the lower third of his right leg. He presented with compartment syndrome of the right leg and foot [Figure 1a and b]. HBO therapy was administered for six sessions following admission. The patient recovered from the syndrome without any surgical intervention [Figure 1c].

\section{Case 2}

An 8-year-old boy was admitted with a snakebite injury to the dorsum of his right foot. He presented with compartment syndrome and discoloration at the bite site [Figure 2a]. HBO therapy was administered for six sessions following admission, and sequential evaluation was performed [Figure 2b-d]. After demarcation of the nonviable tissue, debridement, and skin grafting was done [Figure 2e].

\section{Case 3}

A 45-year-old male presented with soft tissue loss measuring $8 \mathrm{~cm} \times 7 \mathrm{~cm} \times 2 \mathrm{~cm}$ over the lower third of his right leg and lateral aspect of his ankle [Figure 3a]. Wound debridement was performed, and the resultant soft tissue defect was covered with a left anterolateral thigh flap [Figure 3b]. Six sessions of HBO therapy was performed postoperatively.

\section{DISCUSSION}

Snake envenomations have the highest incidence in Asian countries resulting in gross morbidity and mortality. Males are more commonly affected than females, as they are mostly involved in farming and outdoor activities. The predominant age group affected is those between 20 and 40 years. ${ }^{|3|}$ The most common symptoms are pain and swelling of the bitten region. Systemic signs include 
Table 1: The admission of patients with snakebite injuries during the period of October 2012-October 2013

\begin{tabular}{|c|c|c|c|c|c|c|c|}
\hline \multirow[t]{2}{*}{ Year } & \multirow[t]{2}{*}{ Month } & \multicolumn{2}{|c|}{ In patient snake bite } & \multirow{2}{*}{$\begin{array}{l}\text { ASV } \\
\text { given }\end{array}$} & \multirow[t]{2}{*}{ Death } & \multicolumn{2}{|c|}{ Referred to plastic surgery } \\
\hline & & Adult & Pediatrics & & & Pediatrics & Adult \\
\hline 2012 & October & 23 & 3 & 10 & 1 & 1 & 4 \\
\hline 2012 & November & 16 & 2 & 8 & 2 & 0 & 1 \\
\hline 2013 & December & 15 & 5 & 5 & 1 & 1 & 1 \\
\hline 2013 & January & 10 & 1 & 3 & 1 & 0 & 2 \\
\hline 2013 & February & 16 & 2 & 9 & 2 & 0 & 4 \\
\hline 2013 & March & 9 & 4 & 7 & 2 & 0 & 1 \\
\hline 2013 & April & 11 & 7 & 10 & 1 & 1 & 4 \\
\hline 2013 & May & 44 & 8 & 34 & 3 & 1 & 5 \\
\hline 2013 & June & 119 & 2 & 22 & 0 & 1 & 4 \\
\hline 2013 & July & 22 & 2 & 20 & 0 & 0 & 4 \\
\hline 2013 & August & 27 & 1 & 20 & 2 & 1 & 5 \\
\hline 2013 & September & 19 & 3 & 15 & 0 & 0 & 2 \\
\hline 2013 & October & 20 & 4 & 11 & 2 & 1 & 3 \\
\hline Total & 13 months & 351 & 44 & 174 & 17 & 7 & 40 \\
\hline \multicolumn{2}{|c|}{ Number of patients } & 395 & & & & 47 & \\
\hline
\end{tabular}

ASV: anti-snake venom

Table 2: The number of pediatric and adult patients referred to plastic surgery department with snake bite injuries

\begin{tabular}{|c|c|c|c|c|c|c|}
\hline & \multicolumn{2}{|c|}{ Cellulitis } & \multicolumn{2}{|c|}{$\begin{array}{l}\text { Compartment } \\
\text { syndrome }\end{array}$} & \multicolumn{2}{|c|}{ Surgery } \\
\hline & $\begin{array}{l}\text { Upper } \\
\text { limb }\end{array}$ & $\begin{array}{l}\text { Lower } \\
\text { limb }\end{array}$ & $\begin{array}{l}\text { Upper } \\
\text { limb }\end{array}$ & $\begin{array}{l}\text { Lower } \\
\text { limb }\end{array}$ & $\begin{array}{l}\text { Upper } \\
\text { limb }\end{array}$ & $\begin{array}{l}\text { Lower } \\
\text { limb }\end{array}$ \\
\hline $\bar{n}$ & 6 & 17 & 2 & 5 & 7 & 10 \\
\hline Paediatrics & 1 & 1 & 0 & 1 & 1 & 2 \\
\hline Adult & 5 & 16 & 2 & 4 & 6 & 8 \\
\hline Total & 23 & & 7 & & 17 & \\
\hline
\end{tabular}

bleeding, hypotension, cardiotoxicity, and nephrotoxicity that require immediate medical attention. Local signs such as tissue edema, compartment syndrome, and tissue necrosis increases the morbidity and may result in fasciotomy or amputation of the involved extremity. ${ }^{[7,8]}$

ASV administration can reduce progression of the initial tissue damage, but it cannot reverse local tissue damage such as tissue edema, inflammation, compartment syndrome, and necrosis. ${ }^{[7]}$ Although inflammation induced by snake envenomation often mimics infection, true bacterial cellulitis is uncommon, and only affects 3\% of snakebites. ${ }^{[9]}$ Tissues at the point of envenomation may be nonviable regardless of intervention. The adjacent zone consists of variably injured tissues that may recover if the process of inflammation is reduced. Most therapeutic maneuvers are focused on this penumbra of tissue, in an attempt to maximize recovery of the injured marginal tissue. Finally, an outer zone of minimally injured tissues that are not subject to primary injury may be at risk from the processes of secondary injury resulting from the delayed, physiological inflammatory responses to snake bite injury. Occasionally, the quantity of tissue loss and destruction caused by secondary injury can dwarf the actual loss from the primary snakebite. Hence, there is a need for modalities that impede the progress of inflammation, preserve marginal tissue at risk, and prevent ischemic advancement of the injured tissue.

When compartment syndrome occurs in snakebite injuries, there is controversy as to whether or not fasciotomy is required. Snakebite injuries can produce pain, swelling, induration, paresthesias, color changes, absent pulses,

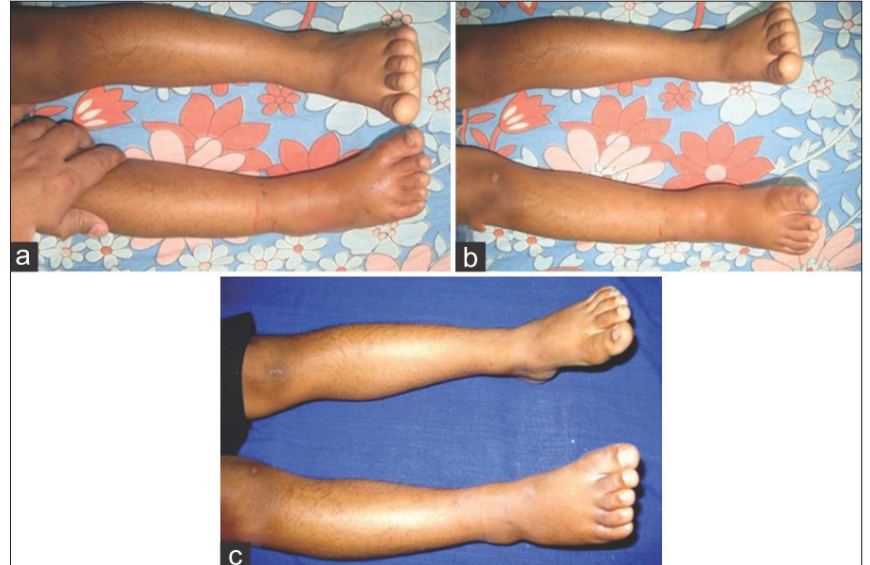

Figure 1: (a) Compartment syndrome right leg and foot lateral view; (b) compartment syndrome right leg and foot medial view; (c) six sessions following hyperbaric oxygenation therapy

and tenderness in the envenomated extremity, mimicking the initial signs of compartment syndrome. However, true compartment syndrome is much less common. ${ }^{[10]}$ In a case series conducted by Tanen et al., ${ }^{[1]}$ only 8/236 (3.4\%) of patients received a fasciotomy or digital dermotomy for compartment syndrome. Measurement of compartment pressures prior to fasciotomy is always recommended. Recent literature indicates that an increase of intracompartmental pressures of up to $30-45 \mathrm{mmHg}$ is an absolute indication for fasciotomy. ${ }^{[12,13]}$ Unfortunately, measurement of intracompartmental pressure is not always possible in a number of medical centers in India, and most of the diagnoses of compartment syndrome are made on clinical grounds alone. Anz et al. ${ }^{[14]}$ reported that $21.2 \%$ of all poisonous snake bites involve fingers. Fingers have small compartments with its small diameters, and the elastic limit of the skin can be rapidly reached. Compartment pressure measurement may not be feasible in cases of digital envenomation, and the diagnosis of compartment syndrome can only be made on clinical grounds. ${ }^{[15]}$ Some authors support early fasciotomy in the treatment of all cases of snake bite envenomation. ${ }^{[15,16]}$ Fasciotomies are not without complication, and may result in disfiguring scars, contractures, nerve damage, leading to significantly lengthening of treatment. ${ }^{[7]}$ 
Table 3: The number of pediatric and adult patients referred to plastic surgery department with snake bite injuries subjected to surgical intervention

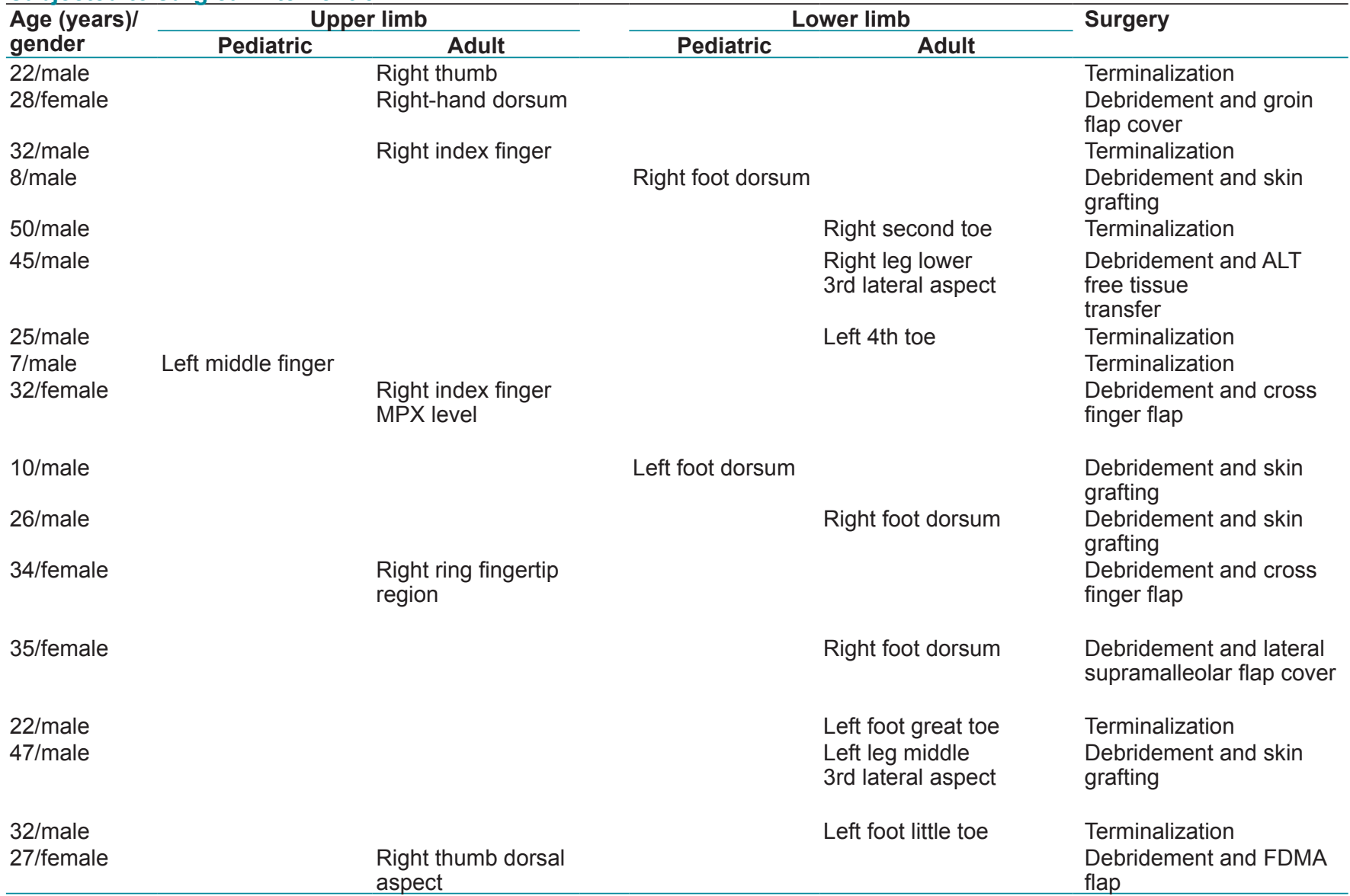

ALT: anterolateral thigh; MPX: middle phalanx; FDMA: first dorsal metacarpal artery

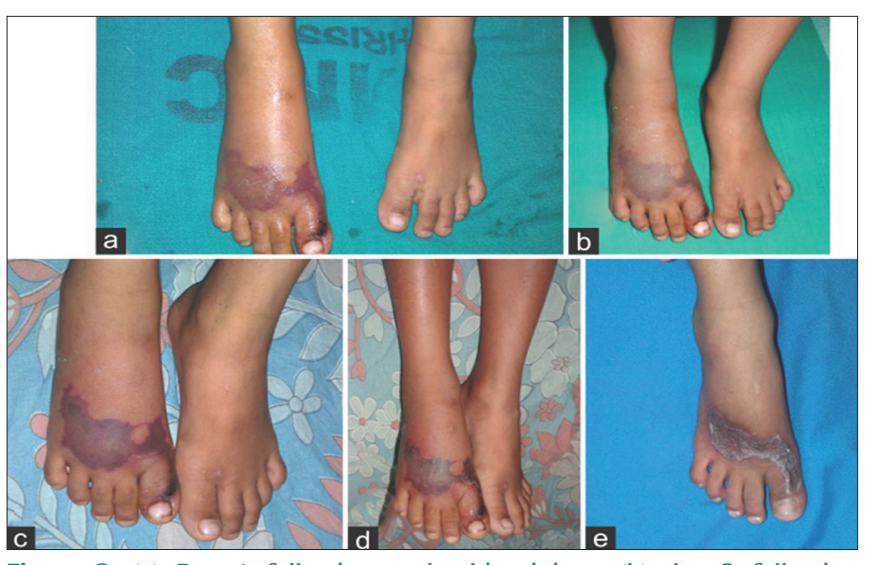

Figure 2: (a) Day 1 following snake bite injury; (b) day 2 following hyperbaric oxygenation therapy; (c) day 3 following hyperbaric oxygenation therapy; (d) day 5 following hyperbaric oxygenation therapy; (e) wound following debridement and grafting

HBO therapy may reduce the penumbra of cells at risk for delayed necrosis and secondary ischemia in snakebite injury patients with early compartment syndrome, ${ }^{[15]}$ breathing of $100 \%$ oxygen under increased ambient pressure prevents reperfusion injury, reduces tissue edema, and reverses sublethal tissue damage. ${ }^{[15,16]}$ Vasoconstriction reduces edema and tissue swelling while ensuring adequate oxygen delivery in snakebite wounds.

In our series, 23 patients were treated for cellulitis and 7 patients for compartment syndrome. In our experience, HBO therapy is a helpful tool when there is an impending compartment syndrome that may require a fasciotomy

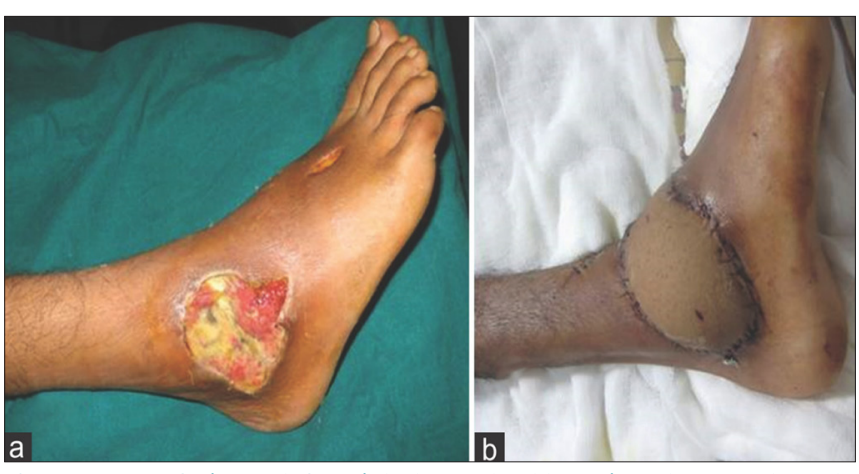

Figure 3: (a) Soft tissue defect right leg and ankle region; (b) anterolateral thigh free tissue transfer done for the soft tissue defect

later. We did not experience any complications related to HBO therapy in our series. It is difficult to be certain whether in the absence of HBO our patients treated with snake envenomation injuries would have progressed to compartment syndrome or tissue necrosis.

As the degree of cellulitis and its severity varied from patient to patient as did the timings of the referrals, there was no standardized starting point for HBO therapy. Six sessions are minimum given to attain a tangible decrease in swelling. Assessment of sensory loss may not be possible in small children, and hence we determine the treatment endpoint based on the decrease in girth of the limb and also the movement of the toes. HBO therapy after surgical debridement, skin grafting or flap reduces edema of the inflamed operation site. Hence, we 
prefer administering HBO therapy for at least six sessions in postoperative patients if they can afford it. Prior to the use of HBO therapy, the general surgeon, who used glycerine magsulf dressings, treated the majority. If this did not improve, this often led to fasciotomies. The exact incidence of fasciotomies is not known. A course of hyperbaric treatment for 6 days is more expensive than fasciotomy, surgical charges, postsurgical dressings and extending patient care combined. As an adjunct to ASV, antibiotics, and surgery, HBO therapy can significantly decrease costs and complications. ${ }^{[17]}$ No studies controlled studies exist that prove the utility of HBO to date. HBO therapy may possibly work by preventing tissue damage that is not frankly necrotic. HBO therapy and debridement have their own roles to play in such injuries. Considering the high incidence of snakebites in the Asian population, further studies into the effectiveness of HBO therapy for this clinical condition is warranted.

In conclusion, snakebite injuries of the extremities are more common in Asian countries. Immediate medical care is almost always necessary. The majority of the patients with snakebite injuries of the extremity present with cellulitis, compartment syndrome, and tissue necrosis. Various treatment modalities including HBO therapy, fasciotomy, surgical debridement, skin grafting, local, and distant flaps may be required to provide an effective management of such injuries. HBO therapy as an adjunct is effective in the treatment of snakebite injuries.

\section{Financial support and sponsorship} Nil.

\section{Conflicts of interest}

There are no conflicts of interest.

\section{REFERENCES}

I. Al Qahtani MA, Altheaby A, Al Anazi T, Al Saad K, Binsalih S, Al Helail
M. Snake bite complicated by acute kidney injury secondary to necrotizing glomerulonephritis. Saudi J Kidney Dis Transpl 20 I4;25: I 259-62.

2. Halesha BR, Harshavardhan L, Lokesh AJ, Channaveerappa PK, Venkatesh KB. A study on the clinic-epidemiological profi le and the outcome of snake bite victims in a tertiary care centre in Southern India. J Clin Diagn Res 2013;7:122-6.

3. Singh V, Digra SK, Slathia SS, Kakkar T. Hemothorax following snakebite. Indian Pediatr 20I2;49:242-3.

4. Bhalla G, Mhaskar D, Agarwal A. A study of clinical profile of snake bite at a tertiary care centre. Toxicol Int 2014;2I:203-8.

5. Harshavardhan L, Lokesh AJ, Tejeshwari HL, Halesha BR, Metri SS. A study on the acute kidney injury in snake bite victims in a tertiary care centre.J Clin Diagn Res 2013;7:853-6.

6. Bosak AR, Ruha AM, Graeme KA. A Case of neurotoxicity following envenomation by the Sidewinder rattlesnake, Crotalus cerastes. J Med Toxicol 20।4; 10:229-31.

7. Gold BS, Dart RC, Barish RA. Bites of venomous snakes. N Engl J Med 2002;347:347-56.

8. Lalloo DG, Theakston RD. Snake antivenoms. J Toxicol 2003;41:277-90.

9. Lavonas EJ, Ruha AM, Banner W, Bebarta V, Bernstein JN, Bush SP, Kerns WP 2nd, Richardson WH, Seifert SA, Tanen DA, Curry SC, Dart RC; Rocky Mountain Poison and Drug Center, Denver Health and Hospital Authority. Unified treatment algorithm for the management of crotaline snakebite in the United States: results of an evidence-informed consensus workshop. BMC Emerg Med 201 I; I I:2.

10. Tanen D, Ruha A, Graeme K, Curry S. Epidemiology and hospital course of rattlesnake envenomations cared for at a tertiary referral center in Central Arizona. Acad Emerg Med 200 I;8: 177-82.

II. Tanen DA, Danish DC, Grice GA, Riffenburgh RH, Clark RF. Fasciotomy worsens the amount of myonecrosis in a porcine model of crotaline envenomation. Ann Emerg Med 2004;44:99- 104.

12. Schexnayder SM, Schexnayder RE. Bites, stings, and other painful things. Pediatr Ann 2000;29:354-8.

13. Lykissas MG, Koulouvaris P, Kostas-Agnantis I, Gkiatas I, Milionis $\mathrm{HJ}$, Mavrodontidis AN. Snakebites of fingers or toes by Viperidae family members: an orthopaedic approach. Acta Orthop Belg 20I I;77:246-5I.

14. Anz AW, Schweppe M, Halvorson J, Bushnell B, Sternberg M, Andrew Koman L. Management of venomous snakebite injury to the extremities.J Am Acad Orthop Surg 2010;18:749-59.

15. Rainer PP, Kaufmann P, Smolle-Juettner FM, Krejs GJ. Case report: hyperbaric oxygen in the treatment of puff adder (Bitis arietans) bite. Undersea Hyperb Med 2010;37:395-8.

16. Bhutani S,Vishwanath G. Hyperbaric oxygen and wound healing. Indian J Plast Surg 20I2;45:3 I 6-24.

17. Sahni T, Hukku S, Jain M, Prasad A, Prasad R, Singh K. Recent advances in hyperbaric oxygen therapy. Med Update 2004; 14:632-9. 